\title{
TO COOPERATE OR TO COMPETE: A GAME THEORETIC ANALYSIS ON PORTS IN MALAYSIA AND SINGAPORE
}

\author{
Joshua IGNATIUS ${ }^{*}$, Tian Siang TAN $^{2}$, Lalitha DHAMOTHARAN ${ }^{3}$, Mark GOH ${ }^{4}$ \\ ${ }^{1,3}$ Warwick Manufacturing Group, University of Warwick, Coventry, CV4 7AL, UK \\ 1, 2 School of Mathematical Sciences, Universiti Sains Malaysia, 11800 Minden, Penang, Malaysia \\ ${ }^{3}$ School of Management, Universiti Sains Malaysia, 11800 Minden, Penang, Malaysia \\ ${ }^{4}$ NUS Business School and the Logistics Insitute-Asia Pacific, National University of Singapore, \\ 15 Kent Ridge Drive, Singapore
}

Received 16 November 2015; accepted 22 May 2016

\begin{abstract}
The busiest container ports in the world are mostly situated in the Asian region, thus intensifying inter-port competition. Particularly unique in this region, is the shared history between Malaysia and Singapore, which was once ruled-under the British empire, has since become economic rivals for the Far East - Europe trade route. This provides a suitable context to investigate whether competition or a strategic alliance should be adopted for ports in terms of its benefit to the industry in the region as a whole. Specifically, this paper analyses the ocean freight traffic demand for the Far East-Europe route among three main transshipment ports located in Malaysia and Singapore: Port of Singapore (PSA), Port Klang (PKL), and Port of Tanjung Pelepas (PTP). The paper provides a scenario analysis of the 3-way interaction through a game theoretic model. The results suggest that a strategic alliance between PSA and PTP generates greater profitability to the current hub and spoke network, while PKL should not commit to any cooperative strategy with either PSA or PTP.
\end{abstract}

Keywords: port competition, port cooperation, game theory, Singapore, Malaysia, transshipment.

JEL Classification: C71, C72.

\section{Introduction}

The introduction of containerization in the mid-1950s by SeaLand resulted in an efficient method of transferring goods. In the 1970s, the usage of containers substituted the conventional break bulk trades and general cargo handling services. As the number of container ports increased in the 1980s, the network strategy began to shift from point-to-point services to hubs-and-spoke services. Major transshipment hubs emerged during this period through their intermediary location along the major shipping trading routes.

*Corresponding author. E-mail: j.ignatius@warwick.ac.uk 
In addition, market expansion due to liberalization leading to the opening of manufacturing locations in labour competitive countries has moved logistics operations to Asia. This is largely due to the rapid economic growth of China's hinterland and its role as the world's manufacturing centre. The massive entry of Chinese ports in the global shipping network directly intensified the competition among container ports in the region (Guerrero, Rodrigue 2014; Yeo 2010). This paved the way for an increase in cross border networks and led to the growth of global container traffic especially on the Far-East route, where the ports of Singapore and Malaysia are located.

Table 1 shows the world's top 20 major container ports and their respective container traffic in 2002 and 2013. The development of container terminals in the Asia Pacific region has been more dynamic compared to the other regions elsewhere, as nine of the top $10 \mathrm{ma}-$ jor world ports are located in this region. The ports of Shanghai and Singapore are the two leading container ports globally, handling 33.62 million TEUs and 32.6 million TEUs in 2013 respectively. Port Klang (PKL) and Port Tanjung Pelepas (PTP) are in the top 20 list of world container ports, handling 10.35 and 7.42 million TEUs, respectively.

Table 1. Top 20 major container ports globally (source: American Association of Port Authorities)

\begin{tabular}{|c|c|c|c|c|c|}
\hline \multirow{2}{*}{$\begin{array}{c}\text { Rank } \\
(2013)\end{array}$} & \multirow{2}{*}{$\begin{array}{c}\text { Rank } \\
(2002)\end{array}$} & \multirow{2}{*}{ Port, Country } & \multicolumn{2}{|c|}{$\begin{array}{c}\text { Container Throughput, } \\
\text { ('000 TEUs) }\end{array}$} & \multirow{2}{*}{$\begin{array}{c}\begin{array}{c}\text { Growth Rate } \\
(\%)\end{array} \\
2013 / 2002\end{array}$} \\
\hline & & & 2013 & 2002 & \\
\hline 1 & 4 & Shanghai, China & 33,617 & 8,620 & 389.99 \\
\hline 2 & 2 & Singapore, Singapore & 32,579 & 16,941 & 192.31 \\
\hline 3 & 6 & Shenzhen, China & 23,278 & 7,614 & 305.73 \\
\hline 4 & 1 & Hong Kong, China & 22,352 & 19,144 & 116.76 \\
\hline 5 & 3 & Busan, South Korea & 17,612 & 9,436 & 186.65 \\
\hline 6 & 33 & Ningbo-Zhoushan, China & 17,327 & 1,860 & 931.56 \\
\hline 7 & 16 & Qingdao, China & 15,520 & 3,410 & 455.13 \\
\hline 8 & 28 & Guangzhou Harbor, China & 15,309 & 2,180 & 702.25 \\
\hline 9 & 13 & Dubai, United Arab Emirates & 13,600 & 4,194 & 324.27 \\
\hline 10 & 25 & Tianjin, China & 12,997 & 2,410 & 539.29 \\
\hline 11 & 7 & Rotterdam, Netherlands & 11,664 & 6,515 & 179.03 \\
\hline 12 & 11 & Port Klang, Malaysia & 10,350 & 4,533 & 228.33 \\
\hline 13 & 5 & Kaohsiung, Taiwan, China & 9,979 & 8,493 & 117.50 \\
\hline 14 & 26 & Dalian, China & 9,912 & 1,367 & 725.09 \\
\hline 15 & 9 & Hamburg, Germany & 9,257 & 5,374 & 172.26 \\
\hline 16 & 10 & Antwerp, Belgium & 8,578 & 4,777 & 179.57 \\
\hline 17 & 36 & Xiamen, China & 8,008 & 1,750 & 457.60 \\
\hline 18 & 8 & Los Angeles, U.S. & 7,869 & 6,106 & 128.87 \\
\hline 19 & 22 & Tanjung Pelepas, Malaysia & 7,417 & 2,660 & 278.83 \\
\hline 20 & 12 & Long Beach, United States & 6,731 & 4,524 & 148.78 \\
\hline
\end{tabular}


The globalization process fuelled by the increasing international trade led to the rapid development of the maritime transport industry in Asia. Shipping lines deploy ever-larger vessels to achieve better scale economies by reducing the unit cost per TEU (Editorial 2013). Container ports have to project future demand into building better port equipment and infrastructure such as larger cranes and larger container yard space to serve even larger vessels in the future. However, approximately three quarters of Asian container ports are claimed to operate inefficiently, owing to technical inefficiencies rather than scale inefficiencies (Hung et al. 2010).

Among the four major ports located in the South East Asia region are the Port of Singapore, Port Klang, Port of Tanjung Pelepas, and Laem Chabang. This is where container traffic is most concentrated within the first three ports; whereas Laem Chabang Port acts more as a local gateway port that relies on the larger hubs of Singapore and Hong Kong (Wang, Cullinane 2014). Therefore, it will be interesting to investigate the interaction of the first three ports that are homogenous in terms of location and their role in serving the Far East-Europe trading route. The only related research was the one conducted by Asgari et al. (2013), which analysed how the game theoretic approach was integrated with the data envelopment analysis (DEA) method in analysing the competition and cooperation strategies among three parties: two hub ports (Hong Kong and Singapore) and shipping companies.

Anecdotal evidence suggest that the competing head among the ports may not be a sustainable strategy, especially when, ceteris paribus, cost is the main motivator for carriers to switch ports. We investigate the possible port alliances, and whether this would generate economies of scope for the overall industry as well as contribute to the economies of scale for the individual ports. Hence, the main objective of this study is to explore both cooperative and non-cooperative (competitive) opportunities that lie among the three major transshipment container ports, located in the proximate region. The three ports are the Port of Singapore (PSA), Port Klang (PKL), and the Port of Tanjung Pelepas (PTP).

We would like to highlight that our main intention in this study is not to focus on developing a new game theoretic model but to address the current research gap of assessing the non-cooperative and cooperative opportunities that lie among the three corresponding ports located in the proximate region. To the best of our knowledge, research that explore this particular area of study has yet to be undertaken.

This study is organized as follows: Section 1 provides the industry context of the three ports. Section 2 reviews the relevant literature on the maritime industry. Section 3 presents the methodology and the mathematical formalization of the game theoretic model with its relevant assumptions. Section 4 presents the findings. Section 5 concludes the study with some implications and suggestions for future research.

\section{Industry review}

\subsection{Maritime industry development}

There are no signs of the maritime industry slowing, as the larger container vessels continue to be developed under increasing inter-modality, growing competitive pressure, shipping network model changes, and increasing investment by shipping companies in container 
terminals (Van de Voorde 2005). Other notable developments include more consolidation through mergers and acquisitions (M\&A), joint ventures, take-overs, and strategic alliances among carriers (Sys 2009; Yeo 2010).

The shipping industry reformation has created major shipping alliances dominating the world trade routes by providing global services, thus collectively increasing their market power. The shipping lines' strategies are affected by numerous factors, which include the deployment of larger vessels, partnerships among the liners, technological and organizational development as well as safety and environmental aspects (Van de Voorde 2005). Although liner shipping alliances and cooperation continue to play a central role in the operations and long-term viability of shipping companies (Panayides, Wiedmer 2011), forming an alliance is not the only strategy for surviving in the industry. Alix et al. (1999) have analysed the case of CP Ships, a Canadian shipping company that has grown through the direct acquisition of firms that offer the business complementarity advantages before it was purchased by Hapag Lloyd in 2005.

The maritime industry's growth can be illustrated through the interdependent relations between the growth of container terminals and the shipping lines' deployment of ever-larger container vessels. In order to gain a better competitive advantage, container terminals must respond rapidly to a surge in market demand and be flexible to industry changes. The high intensity of competition among the container terminals has also encouraged carriers to seek new avenues for reducing operational costs.

The globalization of production activities and liberalization of markets have increased international trade activities. The increment in international trade activities, as well as the development of intermediary hubs are contributors to containerization growth (Yeo 2010). This indirectly intensifies competition among the neighbouring ports operating within a region. Ports are incentivised if they gain improved position as a global hub port, as a result of the increased throughput from their current and potential customers through competition. Although ports can be in direct competition, the development of new ports in their vicinity appears to complement rather than threaten the growth of hub port cities (Lee et al. 2008). The rapid growth of the shipping industry and container vessels have pressured ports to respond with new terminals, new cranes, and to form alliances or M\&As as a means to maintain service quality levels, and to guarantee the continued success of the ports. Forming an alliance among the ports may lead to a win-win situation. Recently, the Ports of Seattle and Tacoma have finally decided to form an alliance to end their decades-long rivalry in order to retrieve their lost market share (Garnick 2013). Rather than having the ports competing against each other in terms of market share, a port alliance can increase their overall combined competitiveness.

\subsection{Port of Singapore, PSA}

The British East India Company founded the modern port of Singapore in 1819 as an entrepôt-trading centre. As a city-state, Singapore has lived up to its reputation as a "smart city" and an international hub by improving its overall economic competitiveness through a successful national network structure in exploiting information and communication tech- 
nology (Mahizhnan 1999). The Port of Singapore Authority was corporatized and renamed as the PSA Corporation in October 1997. The government-owned entity, Temasek Holdings (Private) Limited, holds $100 \%$ of the shares of the privatised PSA Corporation. The regulatory and statutory roles of the former Port of Singapore Authority have been transferred to the Maritime and Ports Authority (MPA) since the latter's establishment in February 1996 (Cullinane et al. 2007).

Although there are many ports (particularly, PKL and PTP) in the region where PSA is located, many shipping lines still choose to call at PSA due to its high efficiency. In absolute terms, PSA still handles more container traffic than PKL and PTP combined (Table 1). Since PSA has pursued a policy of providing multi-user berths, carriers are not allowed to operate their own terminals. However, PSA has several highly desirable attributes in achieving scale economies for the port, such as its strategic location, and the free trade business environment (Lee et al. 2008). Shipping lines tend to call at PSA as its operational efficiency, greater range of services, and fast turnaround time at its terminals often justify its higher cost than the neighbouring ports. PSA is able to achieve high efficiency (in terms of time, cost, quality, and flexibility) by implementing a successful integration system (Gordon et al. 2005). However, PSA is constrained by the lack of land for her future port development.

Though port performance is positively correlated with both the container terminals' facilities and services, the size of a terminal does not always reflect the terminal's performance. Once a port reaches its maximum volume, there will be limited opportunities for container terminals to expand their facilities; hence service quality upgrading is also necessary to improve their competitiveness (Yeo 2010). In order to meet market expectations, management practices should be improved first before attending to the other issues related to port scale efficiencies (Hung et al. 2010). As such, PSA can only maintain its prominent position by overcoming container traffic congestion and space limitations through better management of its growth in the form of state-of-the-art information technology systems and technological infrastructure (Airriess 2001). PSA faces intense competition from PKL and PTP (Wang and Cullinane 2014).

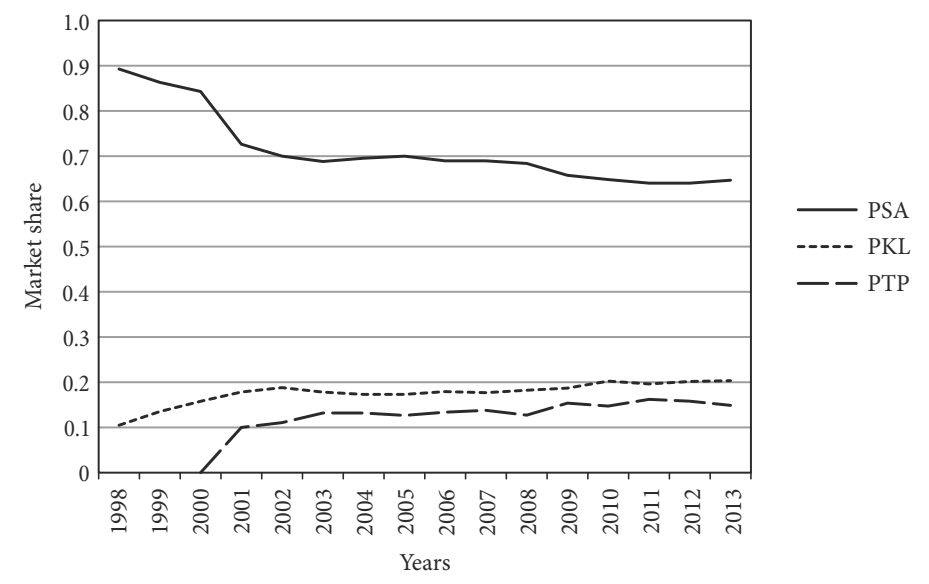

Figure 1. Market share of PSA, PKL, and PTP from 1998 to 2013 


\subsection{Port of Tanjung Pelepas, PTP}

In contrast, PTP offers the opportunity to carriers to operate their own dedicated terminals for greater control over their business. As such, in 2002, PSA lost Maersk and Evergreen to PTP. In the agreement between Maersk and PTP, Maersk purchased 30 percent of PTP's equity, and it was allowed to operate its own terminal. The transshipment hub relocation of Maersk and Evergreen to PTP has reduced PSA's market share to PKL and PTP. Figure 1 illustrates the market share of PSA relative to PTP and PKL from 1998-2012.

Since commencing operations in 1977, the Port of Johor has expanded rapidly. However, with the completion of Phase 4 Pasir Gudang development, the port has reached its maximum expansion capacity. The Johor Port Authority (JPA) began exploring potential new development sites, thus forming PTP. PTP is strategically situated in the southwest of the Johor state, near to the Malaysia-Singapore second link expressway. PTP has been operational since the end of 1999, supporting six berths that are able to handle Post-Panamax vessels. PTP has been scheduled to develop in five phases over a 25 -year period, and will have 12 berths by 2020. Also, 800 hectares of PTP has been declared a free trade zone. PTP is regarded as one of the fastest growing ports in South East Asia.

Under a highly competitive market structure, it is crucial that all port operators secure their major business partners. Losing any of the port's major alliances will cause substantial reduction in container traffic, as is the case of PSA. The establishment of PTP in 2001 caused a diversion of container transshipment traffic (about 3 million TEUs) from PSA. Unlike PSA, PTP can still develop its port infrastructure by acquiring larger land areas. In fact, PTP also gains its competitive advantage over PSA from its relatively lower terminal handling cost, which is estimated to be 30 percent lower than PSA.

Other than its strategic location and high degree of hinterland accessibility, PTP offers approximately 1,000 acres of commercial and industrial free zones, which attracted some of the world's leading firms such as BMW Distribution Parts Centre, Nippon Express, and Maersk Logistics to set up and commence their operations from this port.

\subsection{Port Klang, PKL}

Port Klang, formerly known as Port Swettenham (renamed in January 1972), was fully privatized in 1992. Due to the limitations of river navigation, Port Swettenham was developed and officially opened for service on 15 September 1901, by Sir Frank Athelstane Swettenham. The port experienced rapid expansion and growth between World Wars I and II. During World War II, the port and its facilities were damaged because its location was attacked by the United States Army. However, the port managed to survive, where reconstruction and further expansion has since been done.

Port Klang Authority holds an important position as a statutory corporation and took over the administration of Port Klang from the Malayan Railway Administration. In 1986, the container terminal facilities operated by Port Klang Authority became Klang Container Terminal Berhad as part of the privatization exercise of the government. The Port Klang Authority administers three terminals in the Port Klang area, namely Northport, Southport, and Westport. 
Prior to the establishment of the authority, Northport Southpoint (formerly known as Southport) was the only existing port, under the administration of the Malayan Railway Administration. It is the oldest section of Northport. Rapid demand growth for port facilities at Port Klang and the beginning of containerization saw the development of Northport overtaking the role of Southport. Soon, it became a home to only small coastal ships, tugs, barges, fishing crafts, and inter-island ferries, handling non-containerized cargoes including RO-RO (roll-on/roll-off) shipments.

However, Southpoint is rapidly emerging into a regional conventional transshipment hub due to the major efforts initiated by Northport (Malaysia) Berhad, which owns and operates Southport. Significant upgrading and refurbishing of the facilities and services have been carried out. Northport is the largest container terminal, managed by Northport (Malaysia) Berhad, handling the bulk of Malaysia's import and export cargoes.

The Westport Malaysia Sendirian Berhad (formerly known as Kelang Multi Terminal Sendirian Berhad in 1994), managed Westport, which is located on Pulau Indah. Westport has transformed the island's natural swamplands and sands into a multi-cargo seaport terminal. PKL is currently being developed as the National Load Centre and eventually a hub for the region. Westport focuses mainly on container operations and its productivity is regarded as one of the top five ports in the world. Even though PKL and PTP have made tremendous investments in terms of increasing port capacity and equipment, to cope with the increasing market demand, what makes them incomparable to PSA are the quality of support services offered by the port.

\subsection{Maersk Sealand and Evergreen Marine transshipment hub relocation}

In 1999, the establishment of PTP, at a distance of less than $40 \mathrm{~km}$ from PSA, has intensified competition with PSA. In August 2000, the world's largest shipping company, Maersk, announced its decision to relocate all its mainline transshipment operations, except the West Australia and New Zealand services, from PSA to PTP. The shift was completed in 2001. A year later, a Taiwanese shipping company, Evergreen Marine, announced its relocation decision and signed the terminal service agreement with PTP on 1 April 2002. Since then, most of Evergreen's transshipment activities have been relocated to PTP, after the expiration of the port-use agreement with PSA in August 2002.

Traffic congestion and the lack of advanced infrastructure are the reasons for both Maersk and Evergreen to relocate their transshipment hubs. It has been suggested that the main reason behind the move of Maersk was its desire to operate its dedicated terminal. In 1999, Maersk not only demanded for a terminal handling charges discount, but also sought to operate its own berth and terminal areas at PSA, in order to impose its own procedures and practices on yard operations, and control costs. However, the request was rejected. PSA believed its leading position in the industry was impregnable, and it assumed that Maersk would accept port policies and practices, as there was no other option for the shipping operator. This was until the establishment of PTP.

Despite bearing the higher cost to develop a new terminal, Maersk has decided to relocate most of its transshipment business to PTP in 2000. This decision shifted almost 2 million 
TEUs of container traffic from PSA to PTP, causing a threat to Singapore's quasi-monopoly transshipment hub position in South East Asia. In response to the loss caused by the relocation, PSA has undertaken various strategies to fend off the threats caused by PTP, and to retain its customers with long-term contracts. In July 2002, PSA decided to reduce the handling rate by half for empty containers, while announcing a 10 percent rebate on all terminal charges. The government has proposed allowing shipping companies to develop their dedicated terminals with PSA. PSA has also invested heavily in new infrastructure and technology to keep apace with the growing traffic demand. However, Oliveira and Cariou (2015) note that port efficiencies decline with the intensity of competitive rivalry as port competition is localised.

\section{Literature review}

Competitive strategies among ports are common in the literature, but the applications of game theory in analysing inter-port cooperation are few. A recent study conducted by Asgari et al. (2013), which developed a three-player game theoretic model to investigate the cooperative and non-cooperative strategies amongst three parties (two hub ports and shipping companies) is considered the most relevant to this paper. The cooperative and competitive frameworks presented in Asgari et al. (2013) are generally different from the model framework in this paper. This paper presents five scenarios in terms of the availability of all possible combination of both cooperative and non-cooperative strategies among the three corresponding ports, while Asgari et al. (2013) showed the competition and cooperation between two hub ports, and cooperation between the hub ports and shipping companies.

Nonetheless, inter-port competition and cooperation models have yet to consider more than two-hub ports, with the closest being the competition and collusion in a duopoly (see Bae et al. 2013). By using a numerical experiment on PSA and PTP, Bae et al. (2013) examined the effects of port capacity, prices, and transshipment coefficient on the level of port congestion. In addition, the profit margin was also proven to be higher in the social optimum model than the cooperative model, while the port cooperative model yielded a higher port price than that of the non-cooperative model. However, the focus of our research remains in exploring the cooperative opportunities that lie among three ports.

The differences between this research and the work done by Huang et al. (2008) is in the approach used and the case study's port choices. Huang et al. established a Port Container Transshipment Competition Model by combining the quantified SWOT and integer programming methods in analysing the competition among Taiwan's ports (Kaohsiung, Taichung, and Keelung), while our research applied competitive and cooperative game theory approaches in the ports of Malaysia and Singapore, namely PSA, PKL, and PTP.

According to the literature, many factors affect the competitiveness of ports. The main factor would be port efficiency (Tongzon 2009; Ishii et al. 2013), which can be improved through proper management, production scales, and technological development (Cheon et al. 2010; Monios, Wilmsmeier 2012). Though some studies (e.g. Cullinane, Khanna 2000; Seabrooke et al. 2003; Tongzon 2009) have identified geographical location as a factor affecting competitiveness, we argue that this should be a prerequisite for operating a port rather than a competitive factor. 
From this, we can relate to the point that ports could undertake developmental progress as this will help improve port performance and competitiveness in the industry. Wide range port connectivity (Tongzon 2009) along with adequate port facilities (Cullinane, Khanna 2000), can impact port throughput. This is evident from PSA's leading position as one of the world's busiest ports. Likewise, terminal handling charges (Fung et al. 2003; Huang 2008; Tongzon 2009; Ishii et al. 2013) and effective technological implementation (Gordon et al. 2005; Mahizhnan 1999) could also foster a port's overall performance as well. Globalization and shipping alliances, development of ever-larger container vessels, inter-modality, and intense competition within the port industry are drivers for both port competition and cooperation (Song 2003).

The three ports analysed in this study are located in the Straits of Malacca and Singapore. Geographically, the straits are the world's busiest shipping lane, connecting major economies, such as Japan, China, South Korea, and the Middle East. The littoral nations (Singapore, Malaysia, and Indonesia) along the Straits benefit by locating on the major artery of maritime traffic. However, due to the narrow and shallow characteristics of the straits, collisions often occur, requiring vessels operating there to reroute through the Sunda or Lombok Straits if the Straits of Malacca and Singapore were congested. Impact analysis done by Qu and Meng (2012) shows that if the straits were shut, international trading activities would be largely affected. Hence, the Straits are indubitably important for international trades, and this is one of the reasons why this research focuses on the three respective ports that lie in the two important Straits.

\subsection{Port competition and cooperation}

Woo et al. (2011), summarized research on the seaport industry from published academic journals during 1980 to 2000s. According to Bichou and Gray (2005) organizational and industry complexity impact a port's functional, operational, and institutional role. For example, ports adapt by either integrating horizontally by merging with or own terminals beyond the home port, and/or integrating vertically by providing a wider range of logistics services.

It is recognized that certain forms of competition and cooperation strategies are needed to maintain port competitiveness. Scholars have proposed strategic alliances (cooperative relationships) between adjacent container ports as a strategic option rather than cooperation (Woo et al. 2011; Avery 2000; Song 2002, 2003; Low et al. 2009; Asgari et al. 2013). Ports that engage in cooperative relationships will gain complementary effects from each other in terms of the wider service networks.

Saeed and Larsen (2010) apply a two-stage game model that involves three container terminals (Karachi International Container Terminal, Pakistan International Container Terminal, and Karachi Port Trust) located in Karachi Port, Pakistan. Grand coalition forms among the three terminals are claimed to be able to generate high benefits for the respective terminals. From the model, an competitor (Qasim International Container Terminal) enjoys a free rider effect from the grand coalition, which is due to the incremental of the price and market share. 
The imperfect information in the market causes players to deviate from equilibrium in a cooperative game structure, in either finitely or infinitely repeated games (Bruttel et al. 2012). Collusions or alliances are rather unstable if players are unable to perfectly monitor each other's decisions. In fact, the existence of a certain level of intra-alliance competition will most likely weaken the mutual trust among the alliance members (Midoro, Pitto 2000). Therefore, a good regime of reward and punishment is necessary to form a stable cooperative model, whenever a negative demand shock occurs, to maintain adequate incentives for the cooperation to be sustainable (Roos 2006). Studies have been done on cooperative strategies among shipping lines. For instance, Das (2011) analyses the factors that affects shipping lines decision on whether they should enter intoa partnership or an acquisition. However, by applying the core theory, Song and Panayides (2002) show that shipping alliances tend to be unstable.

PSA is subject to challenges from the establishment of PTP (Slack, Wang 2002). The work by Lam and Yap (2008) shows that competition from both PKL and PTP has had negative impacts on PSA's container transshipment. Furthermore, globalization has led to intense competition amongst these ports seeking to gain a larger market share. However, competition between PKL and PTP is less intense in comparison to that with PSA. As observed by Low et al. (2009), the trend in the Asian port industry is heading towards a competitive rather than a cooperative situation. Previous studies have not focused on any cooperative or competitive approach on the three corresponding ports; this study combines the competition approach with the cooperative approach on these three ports.

In the late 1990s, the initiation of the Indonesia-Malaysia-Singapore Growth Triangle, formerly known as the Singapore-Johor-Riau region (SIJORI), illustrates the idea of crossborder cooperation and the economic complementarity among the three littoral nations, where Singapore was to supply capital, while Johor and Riau were to provide unregulated land area and cheap labour (Sparke et al. 2004). The Indonesia-Malaysia-Singapore Growth Triangle is a model for cooperation rather than competition; however, cooperation in the area is still lacking. It has been suggested that if Johor Bahru (Iskandar Malaysia) and Singapore were to cooperate, they would have more financial resources to invest in the sustainability of their economies. Therefore, the rationale of these three ports' cooperative strategies is that the ports may complement one another rather than being in constant competition. The new port (PTP) development in the region appears to complement PSA (Lee et al. 2008). In addition, Rizzo and Glasson (2012) assert that shifting from the Indonesia-Malaysia-Singapore Growth Triangle model to the MCR (Mega-City Region between Singapore and Malaysia) could provide a better understanding of the importance of the two nations' cross-border dynamics.

Conflicts between efficiency and individual rationality in a collusion model are often depicted in the prisoners' dilemma concept. In the cooperative model, we assume the ports involved will cooperate in a strategic alliance. In the context of this paper, the term "strategic alliance" conceptually refers to the various forms of inter-port cooperative agreements and excludes M\&As and joint ventures (JVs). Since forming or leaving an alliance involves relatively lower costs and has higher flexibility compared to the situation where mergers or JVs are to be dissolved. Therefore, alliances are highly unstable as compared to the mergers and JVs because information asymmetry leads to cheating and negative competition (Mody 1993). 
Reducing the number of alliance members reduces the complexity of the alliance structure. Different roles and contributions, along with sales and marketing coordination will guarantee the stability of the alliance and efficiency among members (Midoro, Pitto 2000). Therefore, this paper proposes a three-player model rather than incorporating more players to reduce the complexity of the structural models.

\section{Methodology}

To investigate the unexplored cooperative opportunity that lies among the three corresponding ports (PSA, PKL, and PTP), it is necessary for us to view the industry from every possible prospect.

Although Asgari et al. (2013) found that there exists a potential in assessing the competitive and cooperative approaches between PSA and PTP, previous studies have not focused on any cooperative or competitive strategies on the two corresponding ports. This study incorporates the competition approach with the cooperative approach on these two ports, together with PKL, as inter-port complementarity was found to exist between PSA and PKL (see Wang, Cullinane 2014). The key question is whether the three ports should cooperate with each other, or should they just maintain their status quo.

There is still no actual cooperative approach that has been taken by the ports. Therefore, we do not have any data to be collected for empirical evidence. Our intention of the study of the ports of Singapore and Malaysia is to explore the cooperative opportunity that lies among the three ports by using the approach of game theory. This study categorizes the competition and cooperation model as five cases.

Case 1: All three ports do not engage in any cooperation strategy.

Case 2: Only PSA and PKL form port alliance, while PTP stays out.

Case 3: Only PSA and PTP form port alliance, while PKL stays out.

Case 4: Only PKL and PTP form port alliance, while PSA stays out.

Case 5: All three ports cooperate and form a strategic port alliance.

The data collected for the three corresponding ports are from the years 1999 to 2011, covering the mean annual container traffic growths for all three ports. The mean annual container traffic growths are used to anticipate the profit gain of each port under the five different cases.

For cases where the cooperative strategy was applied to the ports (partial or complete cooperation), the overall profit for the alliance formed was divided according to the ratio of the number of container berths owned by the ports. From the data obtained, we are able to determine the minimum criterion for the ports to form a strategic alliance by applying the characteristic function of super additivity. The final results are then inserted into a payoff matrix (see Table 7) for comparison and discussion.

Research is focused on the shipping lines instead of the port industry due to the limitations in obtaining sufficient data to meet the statistical assumptions. Hence, this study resorts to game theoretic models instead of statistical models to analyse the data in Table 2. 
Table 2. Data for PSA, PKL, and PTP

\begin{tabular}{lcccc}
\hline & $\begin{array}{c}\text { PSA } \\
(i=1)\end{array}$ & $\begin{array}{c}\text { PKL } \\
(i=2)\end{array}$ & $\begin{array}{c}\text { PTP } \\
(i=3)\end{array}$ & Total \\
\hline Container Traffic (TEU), $q_{i}$ & $30,000,000$ & $9,000,000$ & $7,500,000$ & $46,500,000$ \\
\hline Terminal Handling Charge (US\$), $p_{i}$ & 100 & 70 & 70 & \\
\hline Container Handling Cost (US\$), $c_{i}$ & 70 & 56 & 56 & \\
\hline Profit Margin (US\$) & 30 & 14 & 14 & \\
\hline Number of Container Berths, $\alpha_{i}$ & $63^{*}$ & 24 & 12 & 99 \\
\hline Mean Annual Container Traffic Growth $(\%), \beta_{i}$ & 5.71 & 14.00 & 14.22 & 8.37 \\
\hline
\end{tabular}

Notes ${ }^{\star}$ Including 11 container berths from Jurong Port.

\subsection{Game theory}

Game theory has been successfully applied to solve various decision problems. Game theory provides a framework based on the construction of rigorous models that describe situations of conflict and cooperation between rational decision makers. The literature suggests that a cooperative game theoretic approach is suitable for analysing decision making in the logistics process, involving retailers, manufacturers and suppliers. In this context, Jia et al. (2013) and Mahdiraji et al. (2014) assessed the vertical coalition by performing experimental studies using the game theoretic approach. Jia et al. (2013) and Mahdiraji et al. (2014) covered all possible scenarios, which show that cooperation strategies outdo competitive strategies. However, these two studies are rather different from our research, which targets the context of horizontal coalition opportunities that exist among the three ports. We shall begin the methodology by introducing some formal language and notations of game theory that are necessary for the analysis, as shown in Table 3.

Table 3. Notations

\begin{tabular}{cl}
\hline$i$ & Index $(i=1,2,3)$ to represent PSA, PKL, and PTP, respectively \\
\hline$q_{i}$ & Container traffic handled by port $i$ (TEUs) \\
\hline$Q$ & Total container traffic handled by PSA, PKL, and PTP (TEUs) \\
\hline$p_{i}$ & Port $i$ 's container handling charges (US\$) \\
\hline$c_{i}$ & Port $i$ 's container handling costs (US\$) \\
\hline$T R_{i}$ & Port $i$ 's total revenue (US\$) \\
\hline$T C_{i}$ & Port $i$ 's total cost (US\$) \\
\hline$\pi_{i}^{\bar{C}}$ & Port $i$ 's profit (US\$) when no cooperative strategy is being implemented \\
\hline$\pi_{i}^{C}$ & Port $i$ 's profit (US\$) when the ports form strategic alliance \\
\hline$\alpha_{i}$ & Number of container berths at port $i$ \\
\hline$\delta_{i}$ & Port $i$ 's average rate of annual growth in container traffic (\%) \\
\hline$\partial$ & Overall market growth rate (\%)
\end{tabular}


The model framework that will be used in analysing the three-port competition and cooperation strategies in this paper can be described as a normal-form game. The three basic features in a normal-form game are shown in Table 4.

Table 4. Basic elements in the game model

\begin{tabular}{ll}
\hline Port Game & $\Gamma=\left\langle N,\left\{S_{i}\right\}_{i=1}^{n},\left\{v_{i}(\cdot)\right\}_{i=1}^{n}\right\rangle$ \\
\hline Players & $\begin{array}{l}N=\{1,2,3\}, \text { where the set of index, } i \in N \text { each represents PSA, PKL, and PTP, } \\
\text { respectively. }\end{array}$ \\
\hline Strategies & $\begin{array}{l}S_{i}=\{\text { Cooperative, Competitive }\} \text {, where } i \in N \text {, competitive strategy is port } i \text { 's } \\
\text { strategy to remain status quo, and cooperative strategy is to form a strategic port } \\
\text { alliance among ports. }\end{array}$ \\
\hline Payoffs & $\begin{array}{l}\pi_{i} \text { represents player } i \text { 's profit function associated with his and all his opponents' } \\
\text { strategies, expressed in US\$. }\end{array}$ \\
\hline
\end{tabular}

Definition 1: A normal-form game, $\Gamma$ can be represented by a triple of sets $\Gamma=\left\langle N,\left\{S_{i}\right\}_{i=1}^{n},\left\{\pi_{i}(\cdot)\right\}_{i=1}^{n}\right\rangle$, where $N=\{1,2, \ldots, n\}$ is the finite set of players, $\left\{S_{i}\right\}_{i=1}^{n}$ is the set of all players' strategy sets, with profile strategies, $s=\left\{s_{1}, s_{2}, \ldots, s_{n}\right\}, s_{i} \in S_{i}$, and $\left\{\pi_{i}(\cdot)\right\}_{i=1}^{n}$ is the set of all the players' payoff functions, where $\pi_{i}: S_{1} \times S_{2} \times \ldots \times S_{n} \rightarrow \Re$ for each $i \in N$.

In order to operationalize the game theoretic model, the formation of payoff functions over the strategies is required. Rational players involved in any decision-making situation will require selecting the best strategy among all the alternatives which would result in an optimal outcome that maximizes a payoff function. It is also important to note that individual rationality does not imply group rationality. We shall provide further discussion on the differences of the results for both individual and group rationality in a later stage. Players, who are engaged in individual rationality decision-making, will select the best strategy in their choice set that maximize its payoff regardless of what the other players' choices are. The selected strategy may not necessarily be the best for the combined payoffs of the group or industry.

Definition 2: Rational players involved in any decision problem with a payoff function $\pi(\cdot)$ over strategies is rational if they choose a strategy $a \in A$ that maximizes their payoffs. That is, $a^{\star} \in A$ is chosen if and only if $\pi\left(a^{\star}\right) \geq \pi(a)$ for all $a \in A$.

The players are assumed to be rational and seek to maximize their utility payoffs. Given this assumption, we expect the three ports to seek growth in terms of the container traffic in their business strategy. We assume that the container's throughput growth for PSA, PKL, and PTP is 5.71 percent, 14 percent, and 14.22 percent, respectively. These figures are based on the average growth of containers volume handled by the respective ports from 1999 to 2011 . The data on the berths for 2012 are not available. Due to the nature of this study, there is a limited number of data points that are available. This makes it a challenge to apply predictive models to assess the ports' profits. Nonetheless, we applied the mean growth of the container volume handled for predicting the ports' profits in a base situation where the ports are not 
cooperating. The mean growth of container traffic provides us with the average expected growth of the three ports under the condition of status quo.

If the ports were to cooperate through a strategic port alliance, such an alliance would generate a larger annual container throughput due to the economies of scale. The alliance can expect to handle $Q^{t}=\partial \times Q^{t-1}$ annually, where $Q^{t}$ is the container throughput in period $t$, and $\partial$ is the scale factor due to an alliance. The original container throughput (TEU) for each of the three ports is maintained while the additional container traffic brought by the new network will be allocated between them based on its handling capacity. Here, handling capacity is defined as the number of shipping berths for each port. The handling capacity for the ports is represented in the ratio of 63:24:12 (PSA:PKL:PTP).

Since the official handling rates for both ports are classified, we shall assume that the transshipment rate for a twenty-foot full container load of PSA is US\$100 while PKL and PTP's handling rates are 30 percent lower at US\$70. We note that the amount would be interpreted more as a factor than as an exact value. Thus, it will not impair the final analysis so long as the ratios among ports are preserved. In addition, our ratio preservation is based on the reported estimates that the port price attractiveness of PSA is 30 percent less than PTP (see Kleywegt et al. 2002). Assuming that the cost is 70 percent of the revenue for PSA and 80 percent of the revenue for PKL and PTP respectively, the expected profit margins for all three ports are shown in Table 2.

\subsection{Model development}

We categorize the competition and cooperation model as five cases:

Case 1: All three ports do not engage in any cooperation strategy e.g.: [PSA] vs. [PKL] vs. [PTP].

Case 2: Only PSA and PKL form port alliance, while PTP stays out e.g.: [PSA \& PKL] vs. [PTP].

Case 3: Only PSA and PTP form port alliance, while PKL stays out e.g.: [PSA \& PTP] vs. [PKL].

Case 4: Only PKL and PTP form port alliance, while PSA stays out e.g.: [PKL \& PTP] vs. [PSA].

Case 5: All three ports cooperate and form a strategic port alliance e.g.: [PSA \& PKL \& PTP].

To construct a payoff matrix for the model, we first obtain the profits for each port. Under no cooperation among the ports at time $t$, the ports' profit are

$$
\pi_{i}^{\bar{C}, t=1}=\pi_{i}^{\bar{C}, t=0} \times\left(100+\delta_{i}\right) \%
$$

with

$$
\pi_{i}^{\bar{C}, t-1}=q_{i} \times\left(p_{i}-c_{i}\right) .
$$

When the three ports decide to form a strategic port alliance, each port's profit will be

$$
\pi_{i}^{C, t}=\pi_{i}^{\bar{C}, t-1}+\left(\frac{\alpha_{i}}{\alpha_{i}+\alpha_{-i}}\right)\left(Q^{t}\right)\left(p_{i}-c_{i}\right) .
$$


Substituting $Q^{t}=\partial \times Q^{t-1}$ into equation (3), we have

$$
\pi_{i}^{C, t}=\pi_{i}^{\bar{C}, t-1}+\left(\frac{\alpha_{i}}{\alpha_{i}+\alpha_{-i}}\right)\left(\partial \times Q^{t-1}\right)\left(p_{i}-c_{i}\right) .
$$

After obtaining the payoff matrix for the ports, we determine the minimum criterion for the ports to form a strategic alliance in the context of group rationality. We apply the characteristic function of super additivity,

Hence, we have

$$
U\left(\bigcup_{i=1}^{n} A_{i}\right) \geq \sum_{i=1}^{n} U\left(A_{i}\right)
$$

$$
U(P S A+P L K+P T P) \geq U(P S A)+U(P L K)+U(P T P),
$$

where

and

$$
U(P S A+P L K+P T P)=\sum_{i=1}^{3} \pi_{i}^{C, t=1}
$$

$$
U(P S A)+U(P L K)+U(P T P)=\sum_{i=1}^{3} \pi_{i}^{\bar{C}, t=1} .
$$

\section{Results}

The profits for PSA, PKL, and PTP have been constructed as a payoff matrix for both scenarios: competitive (Case 1) and cooperative environment (Case 5), respectively (see Table 6). The steps are shown in Appendix A.

Aside from the fully competitive (Case 1) or fully cooperative scenario (Case 5), we consider the cases where only two ports form an alliance (i.e. Cases 2, 3, and 4). Based on the results, for overall performance improvement, only a port alliance between PSA and PTP should be formed. PKL is better off not engaging in any cooperative move. This may be due to PKL's distance from PTP and PSA, which may complicate the integration of any port infrastructure services. Further, PKL and its slower growth rate would pose less of a threat to PSA, compared to PTP.

\subsection{Sensitivity analysis}

All of the conditions and criteria where the three ports would, and would not engage in cooperative strategies are assessed using sensitivity analysis. In order to do so, it is crucial for us to obtain the critical value where the three ports are indifferent between complete cooperation and no cooperation (complete competition) among each other. These critical values will be decided by the expected growth value of container traffic after each port cooperates, $\delta_{i}$. Therefore, in the context of the individual rationality decision-making process, where the ports are only interested in maximizing their respective payoffs, the critical values are obtained by equating the profit functions of complete cooperation and no cooperation (refer to Appendix A),

$$
\pi_{i}^{C, t=1}=\pi_{i}^{\bar{C}, t=1} .
$$


In other words, we are comparing the profit functions with cooperation and without cooperation by equating (10) and (11), respectively.

$$
\begin{gathered}
\pi_{i}^{C, t=1}=\pi_{i}^{\bar{C}, t=0}+\left(\frac{\alpha_{i}}{\sum \alpha_{i}}\right)\left(\delta_{i} \times Q^{t-1}\right)\left(p_{i}-c_{i}\right) ; \\
\pi_{i}^{\bar{C}, t=1}=\pi_{i}^{\bar{C}, t=0} \times\left(100+\delta_{i}^{\bar{C}}\right) \%,
\end{gathered}
$$

where $\delta_{i}^{\bar{C}}$ is the mean growth in container volume handled by the respective ports, with $\delta_{1}^{\bar{C}}=5.71, \delta_{2}^{\bar{C}}=14.00$, and $\delta_{3}^{\bar{C}}=14.22$. Table 5 shows the results of the threshold point of $\delta_{i}$ for all 5 cases considered in the analysis. Figure 2 shows how the three ports should act in deciding between their competitive and cooperative strategies.

The critical values of $\delta_{i}$ illustrate that PSA, PKL, and PTP are indifferent between full cooperation and no cooperation when the expected growth of container traffic after cooperating between the ports of PSA, PKL, and PTP is 5.79 percent, 11.18 percent, and 18.92 percent, respectively. Therefore, it is rational for the ports to only engage in a fully cooperative strategy when the percentage growth in container traffic after cooperation exceeds the corresponding critical values, $\delta_{i}$.

In terms of cross-border cooperation, Figure 2 illustrates that PSA will cooperate with PKL only if the cooperative strategy leads to at least a 6.07 percent growth in its container traffic. On the other hand, for PKL to cooperate with PSA, the growth should be at least 11.71 percent. However, for PSA to cooperate with PTP only and vice versa, their respective container growth should be 5.44 percent and 17.78 percent. For domestic cooperation between PKL and PTP, both ports should at least gain 11.45 percent and 19.39 percent in container traffic growth, respectively. It appears that it would take more incentives for a Malaysian port to work with PSA than the reverse. Nonetheless, it also suggests that a greater resistance for Malaysian ports to cooperate among themselves than engaging in a cooperative alliance with their neighbour.

From the sensitivity analysis, the critical values of $\delta_{i}$, also represent the ports' bargaining power in terms of whether they should cooperate or not. Table 5 illustrates that $\delta_{3}>$ $\delta_{2}>\delta_{1}$ for all five cases considered in this study, therefore, we can conclude that PTP is in the highest bargaining position, while PSA has the least bargaining power, and PKL lies in between them.

Table 5. Critical values of $\delta_{i}$ for all 5 cases of the study

\begin{tabular}{ccccc}
\hline \multirow{2}{*}{ Ports } & \multicolumn{4}{c}{ Critical Values, $\delta_{i}$} \\
\cline { 2 - 5 } & Case 1 \& Case 5 & Case 2 & Case 3 & Case 4 \\
\hline PSA $(i=1)$ & 0.0579 & 0.0607 & 0.0544 & N/A $^{*}$ \\
PKL $(i=2)$ & 0.1118 & 0.1171 & N/A & 0.1145 \\
PTP $(i=3)$ & 0.1892 & N/A & 0.1778 & 0.1939 \\
\hline
\end{tabular}

Note: $*$ There are no critical values of $\delta_{\mathrm{i}}$ for the following cells, as the respective ports remain competitive at the given cases, while the rest of the two ports cooperate. 


\begin{tabular}{|l|l|l|}
\hline PSA & \multicolumn{2}{|c|}{ Competition while PKL \& PTP Cooperate } \\
\hline Competition & \multicolumn{2}{|c|}{ PSA Cooperate with PKL Only } \\
\hline Competition & $\begin{array}{l}\text { PSA Cooperate with Both } \\
\text { PKL \& PTP }\end{array}$ \\
\hline Competition & 0.0579 & \multicolumn{1}{c|}{0.0607}
\end{tabular}

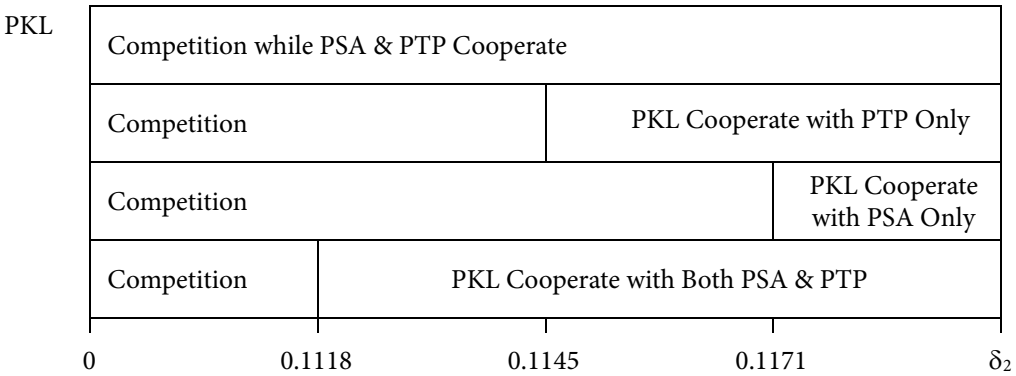

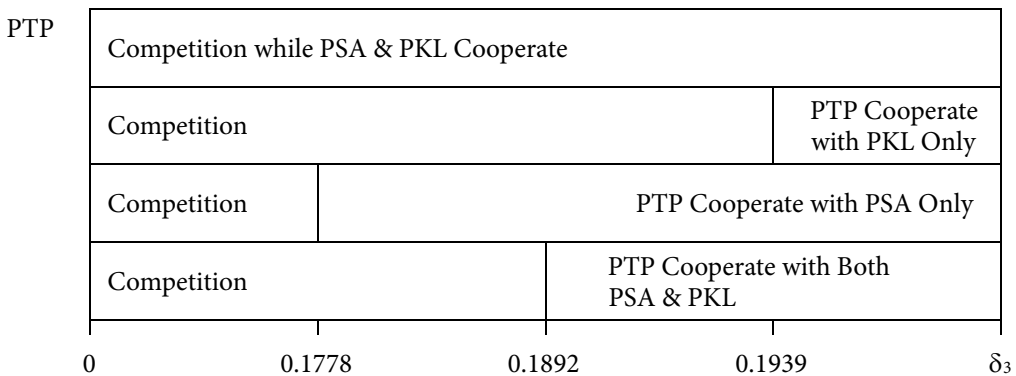

Figure 2. Critical values of $\delta_{i}$ for PSA, PKL, and PTP in deciding to cooperate or compete

From the previous section, we stated that individual rationality does not imply group rationality. The individual player's optimal decision may be the best decision to them, but it may not be necessarily the best decision for the group - the port industry's combined payoffs.

For this reason, we applied the characteristic function of super additivity in order to assess the ports' strategic alliance in the context of group rationality in decision-making. The application of this concept is to determine the minimum criterion for the three ports to form a strategic alliance. To re-emphasize, decision-making in the context of individual rationality is rather different from group rationality. An individual port's decision that yield the best payoff in the individual rationality context does not imply the best in group rationality, i.e. the decision may or may not be the best for the industry as a whole. Hence, we also conducted sensitivity analysis in the context of group rationality to compare the decision outcomes of both individual and group rationalities. 
Solving the characteristic function of super additivity, we have $\partial=0.0747$ in Table 5 (see also Appendix B). Therefore, the criterion where a strategic alliance will benefit all three ports would be a mean annual growth of container traffic (TEUs) of 7.47 percent or more. This is the threshold point for the three ports to decide on whether cooperation leads to better industry overall payoffs or otherwise. Since the average annual container traffic growth in the market is 8.37 percent, it is better for the ports to enjoy an overall container traffic improvement through the strategic alliance. Hence, substituting $\partial=8.37 \%$ into Table 6 yields Table 7. Collaboration among the three ports is expected to lead to better overall port performance, not only in improving the utilization of port capacity, but also in ensuring the region's competitiveness.

Table 6. Payoff matrix for PSA, PKL, and PTP

\begin{tabular}{ccl}
\hline & Profit without Cooperation, $\pi_{i}^{\bar{C}}$ & \multicolumn{1}{c}{ Profit with Full Cooperation, $\pi_{i}^{C}$} \\
\hline PSA, $i=1$ & $\pi_{1}^{\bar{C}, t=1}=\mathrm{US} \$ 951,390,000$ & $\pi_{1}^{C, t=1}=\mathrm{US} \$ 900,000,000+\mathrm{US} \$ 887,727,273 \times \partial$ \\
\hline $\mathrm{PKL}, i=2$ & $\pi_{2}^{\bar{C}, t=1}=\mathrm{US} \$ 143,640,000$ & $\pi_{2}^{C, t=1}=\mathrm{US} \$ 126,000,000+\mathrm{US} \$ 157,818,182 \times \partial$ \\
\hline $\mathrm{PTP}, i=3$ & $\pi_{3}^{\bar{C}, t=1}=\mathrm{US} \$ 119,931,000$ & $\pi_{3}^{C, t=1}=\mathrm{US} \$ 105,000,000+\mathrm{US} \$ 78,909,091 \times \partial$ \\
\hline
\end{tabular}

Table 7. Payoff matrix for PSA, PKL, and PTP

\begin{tabular}{lcccc}
\hline & \multicolumn{4}{c}{ Profit, $\pi_{i}(\mathrm{US} \$)$} \\
\cline { 2 - 5 } & PSA, $\pi_{1}$ & PKL, $\pi_{2}$ & PTP, $\pi_{3}$ & Total Profit \\
\hline $\begin{array}{l}\text { 1. Without Cooperation } \\
\text { [PSA] vs. [PKL] vs. [PTP] }\end{array}$ & $951,390,000$ & $\mathbf{1 4 3 , 6 4 0 , 0 0 0}$ & $\mathbf{1 1 9 , 9 3 1 , 0 0 0}$ & $1,214,961,000$ \\
\hline 2. [PSA \& PKL] vs. [PTP] & $964,559,793$ & $137,477,297$ & $\mathbf{1 1 9 , 9 3 1 , 0 0 0}$ & $1,221,968,090$ \\
\hline 3. [PSA \& PTP] vs. [PKL] & $\mathbf{9 7 6 , 0 7 2 , 5 0 0}$ & $\mathbf{1 4 3 , 6 4 0 , 0 0 0}$ & $111,762,000$ & $\mathbf{1 , 2 3 1 , 4 7 4 , 5 0 0}$ \\
\hline 4. [PKL \& PTP] vs. [PSA] & $951,390,000$ & $133,290,041$ & $108,645,021$ & $1,193,325,062$ \\
\hline $\begin{array}{l}\text { 5. Full Cooperation } \\
\text { [PSA \& PKL \& PTP] }\end{array}$ & $974,302,773$ & $139,209,382$ & $111,604,691$ & $1,225,116,846$ \\
\hline
\end{tabular}

Both PSA and PTP are located strategically in the nexus of the international trading routes, where the relatively shorter distance between the two ports may act as a perfect substitute (Asgari et al. 2013). Although PSA is able to retain its leading position as a global hub port in the region, the market share of PSA has been declining (Fig. 1). No doubt, the rapid development of PTP threatens PSA. Thus, it is rational for the two ports to form a strategic port alliance with each other, albeit this is only temporary. PTP has undergone rapid development since its establishment. The unlimited hinterland access for port and infrastructure development is the main factor that gives competitive advantage to PTP against PSA. 


\section{Conclusions}

It has been suggested that inter-port competition has a direct impact upon the overall maritime transportation system (Wang, Cullinane 2014). This research analysed both competitive and cooperative strategies among the three ports using a game theoretic model. This research found that if PSA and PTP were to form a strategic alliance, it will be an overall performance improvement for the maritime industry in the region, and it will be best for PKL to be left out of the alliance for the benefit of the industry. Surprisingly, the industry as a whole will be less profitable if the two Malaysian ports cooperate instead of acting as competitors. One would expect that ports under the same government will be more likely to perform better than a foreign counterpart. This is possibly because both Malaysian ports are scaled in the same operational manner and the same complementarities of service which are expected from an alliance may not be present, thus may not convert the alliance effectively for technical efficiency improvement.

On the other hand, this inadvertently allows PTP to possess some bargaining power when engaging in a cooperation strategy with PSA, as the latter will be better off cooperating rather than to compete. The reason may be due to PSA's weakening dominant port role in the region. Even though PSA still handles most of the container traffic, and retains its prominent position as one of the busiest container transshipment ports in the world, its market share has been decreasing, while PTP and PKL are experiencing demand growth in their respective container trade.

The analysis in this study can be used to assess the effects of both port competition and cooperation strategies within a geopolitically proximate region. However, the limited data publicly available on this interesting issue bears a major gap in this study. Although this study provides the foundation for further exploration, the formation of more sophisticated game theoretic models have to be left for future studies. Hence, the aim of this research is to narrow the current research gap by assessing any non-cooperative and cooperative approaches that improve the status of these three ports and the overall industry in the region.

For future research, the formation of more sophisticated and complex cooperative and competitive game theoretic models could be taken into account with a comprehensive set of data that covers income, expenditure and structural variables such as revenue, operational costs taking and organizational size. In addition, future research can extend our study by considering the environmental and sustainability issues, and whether this affects the overall competition and cooperation of ports within a geopolitically region.

\section{References}

Airriess, C. A. 2001. Regional production, information-communication technology, and the developmental state: the rise of Singapore as a global container hub, Geoforum 32(2): 235-254. https://doi.org/10.1016/S0016-7185(00)00028-2

Alix, Y.; Slack, B.; Comtois, C. 1999. Alliance or acquisition? Strategies for growth in the container shipping industry, the case of CP ships, Journal of Transport Geography 7(3): 203-208. https://doi.org/10.1016/S0966-6923(98)00048-9

American Association of Port Authorities [online], [cited 1 August 2013]. Available from Internet: http://www.aapa-ports.org. 
Asgari, N.; Farahani, R. Z.; Goh, M. 2013. Network design approach for hub ports-shipping companies competition and cooperation, Transportation Research Part A: Policy and Practice 48: 1-18. https://doi.org/10.1016/j.tra.2012.10.020

Avery, P. 2000. Strategies for container ports: a cargo systems report. London.

Bae, M. J.; Chew, E. K.; Lee, L. H.; Zhang, A. 2013. Container transshipment and port competition, Maritime Policy \& Management 40(5): 479-494. https://doi.org/10.1080/03088839.2013.797120

Bichou, K.; Gray, R. 2005. A critical review of conventional terminology for classifying seaports, Transportation Research Part A: Policy and Practice 39(1): 75-92. https://doi.org/10.1016/j.tra.2004.11.003

Bruttel, L. V.; Guth, W.; Kamecke, U. 2012. Finitely repeated prisoners' dilemma experiments without a commonly known end, International Journal of Game Theory 41(1): 23-47. https://doi.org/10.1007/s00182-011-0272-z

Cheon, S.; Dowall, D. E.; Song, D.-W. 2010. Evaluating impacts of institutional reforms on port efficiency changes: ownership, corporate structure, and total factor productivity changes of world container ports, Transportation Research Part E: Logistics and Transportation Review 46(4): 546-561. https://doi.org/10.1016/j.tre.2009.04.001

Cullinane, K.; Khanna, M. 2000. Economies of scale in large containerships: optimal size and geographical implications, Journal of Transport Geography 8(3): 181-195. https://doi.org/10.1016/S0966-6923(00)00010-7

Cullinane, K.; Yap, W. Y.; Lam, J. S. L. 2007. The port of Singapore and its governance structure, Research in Transportation Economics 17: 285-310. https://doi.org/10.1016/S0739-8859(06)17013-4

Das, S. S. 2011. To partner or to acquire? A longitudinal study of alliances in the shipping industry, Maritime Policy \& Management 38(2): 111-128. https://doi.org/10.1080/03088839.2011.556677

de Roos, N. 2006. Examining models of collusion: the market for Lysine, International Journal of Industrial Organization 24(6): 1083-1107. https://doi.org/10.1016/j.ijindorg.2006.04.004

Editorial. 2013. More Triple-E's ordered at DSME [online], [cited 1 August 2013]. Available from Internet: http://shipandbunker.com/news/apac/823580-more-triple-es-ordered-at-dsme

Fung, M. K.; Cheng, L. K.; Qiu, L. D. 2003. The impact of terminal handling charges on overall shipping charges: an empirical study, Transportation Research Part A: Policy and Practice 37(8): 703-716. https://doi.org/10.1016/S0965-8564(03)00026-0

Garnick, C. 2013. Seattle, Tacoma ports end rivalry, hope to grow jobs, cargo [online], [cited 12 November 2014], Asia/Pacific News, 11 July, 2013. Available from Internet: http://seattletimes.com/ html/businesstechnology/2024720152_portsalliancexml.html

Gordon, J. R. M.; Lee, P.-M.; Lucas Jr., H. C. 2005. A resource-based view of competitive advantage at the port of Singapore, Journal of Strategic Information Systems 14(1): 69-86. https://doi.org/10.1016/j.jsis.2004.10.001

Guerrero, D.; Rodrigue, J.-P. 2014. The waves of containerization: shifts in global maritime transportation, Journal of Transport Geography 34: 151-164. https://doi.org/10.1016/j.jtrangeo.2013.12.003

Huang, W.-C.; Chang, H.-H.; Wu, C.-T. 2008. A model of container transshipment port competition: an empirical study of international ports in Taiwan, Journal of Marine Science and Technology 16(1): 19-26.

Hung, S.-W.; Lu, W.-M.; Wang, T.-P. 2010. Benchmarking the operating efficiency of Asia container ports, European Journal of Operational Research 203(3): 706-713. https://doi.org/10.1016/j.ejor.2009.09.005

Ishii, M.; Lee, P. T.-W.; Tezuka, K.; Chang, Y.-T. 2013. A game theoretical analysis of port competition, Transportation Research Part E: Logistics and Transportation Review 49(1): 92-106. https://doi.org/10.1016/j.tre.2012.07.007

Jia, P.; Mahdiraji, H. A.; Govindan, K.; Meidute, I. 2013. Leadership selection in an unlimited threeechelon supply chain, Journal of Business Economics and Management 14(3): 616-637. https://doi.org/10.3846/16111699.2012.761648 
Kleywegt, A. T.; Goh, M. L.; Wu, G. Y.; Zhang, H. W. 2002. Competition between the ports of Singapore and Malaysia. Technical Report. The Logistics Institute, Georgia Tech, and The Logistics InstituteAsia Pacific, National University of Singapore.

Lam, J. S. L.; Yap, W. Y. 2008. Competition for transhipment containers by major ports in Southeast Asia: slot capacity analysis, Maritime Policy \& Management 35(1): 89-101. https://doi.org/10.1080/03088830701849043

Lee, S.-W.; Song, D.-W.; Ducruet, C. 2008. A tale of Asia's world ports: the spatial evolution in global hub port cities, Geoforum 39(1): 372-385. https://doi.org/10.1016/j.geoforum.2007.07.010

Low, J. M. W.; Lam, S. W.; Tang, L. C. 2009. Assessment of hub status among Asian ports from a network perspective, Transportation Research Part A: Policy and Practice 43(6): 593-606. https://doi.org/10.1016/j.tra.2009.04.004

Mahdiraji, H. A.; Govindan, K.; Zavadskas, E. K.; Hajiagha, S. H. R. 2014. Coalition or decentralization: a game-theoretic analysis of a three-echelon supply chain network, Journal of Business Economics and Management 15(3): 460-485. https://doi.org/10.3846/16111699.2014.926289

Mahizhnan, A. 1999. Smart cities: the Singapore case, Cities 16(1): 13-18. https://doi.org/10.1016/S0264-2751(98)00050-X

Midoro, R.; Pitto, A. 2000. A critical evaluation of strategic alliances in liner shipping, Maritime Policy \& Management 27(1): 31-40. https://doi.org/10.1080/030888300286662

Mody, A. 1993. Learning through alliances, Journal of Economic Behavior and Organization 20(2): 151-170. https://doi.org/10.1016/0167-2681(93)90088-7

Monios, J.; Wilmsmeier, G. 2012. Giving a direction to port regionalisation, Transportation Research Part A: Policy and Practice 46(10): 1551-1561. https://doi.org/10.1016/j.tra.2012.07.008

Oliveira, G. F. D.; Cariou, P. 2015. The impact of competition on container port (in)efficiency, Transportation Research Part A: Policy and Practice 78: 124-133. https://doi.org/10.1016/j.tra.2015.04.034

Panayides, P. M.; Wiedmer, R. 2011. Strategic alliances in container liner shipping, Research in Transportation Economics 32(1): 25-38. https://doi.org/10.1016/j.retrec.2011.06.008

Qu, X.; Meng, Q. 2012. The economic importance of the Straits of Malacca and Singapore: an extremescenario analysis, Transportation Research Part E: Logistics and Transportation Review 48(1): 258265. https://doi.org/10.1016/j.tre.2011.08.005

Rizzo, A.; Glasson, J. 2012. Iskandar Malaysia, Cities 29(6): 417-427. https://doi.org/10.1016/j.cities.2011.03.003

Saeed, N.; Larsen, O. I. 2010. An application of cooperative game among container terminals of one port, European Journal of Operational Research 203(2): 393-403. https://doi.org/10.1016/j.ejor.2009.07.019

Seabrooke, W.; Hui, E. C. M.; Lam, W. H. K.; Wong, G. K. C. 2003. Forecasting cargo growth and regional role of the port of Hong Kong, Cities 20(1): 51-64. https://doi.org/10.1016/S0264-2751(02)00097-5

Slack, B.; Wang, J. J. 2002. The challenge of peripheral ports: an Asian perspective, GeoJournal 56(2): 159-166. https://doi.org/10.1023/A:1022452714114

Song, D.-W. 2002. Regional container port competition and co-operation: the case of Hong Kong and South China, Journal of Transport Geography 10(2): 99-110. https://doi.org/10.1016/S0966-6923(02)00003-0

Song, D.-W. 2003. Port co-opetition in concept and practice, Maritime Policy \& Management 30(1): 29-44. https://doi.org/10.1080/0308883032000051612

Song, D.-W.; Panayides, P. M. 2002. A conceptual application of cooperative game theory to liner shipping strategic alliances, Maritime Policy \& Management 29(3): 285-301. https://doi.org/10.1080/03088830210132632 
Sparke, M.; Sidaway, J. D.; Bunnell, T.; Grundy-Warr, C. 2004. Triangulating the borderless world: geographies of power in the Indonesia-Malaysia-Singapore growth triangle, Transactions in the Institute of British Geographers 29(4): 485-498. https://doi.org/10.1111/j.0020-2754.2004.00143.x

Sys, C. 2009. Is the container liner shipping industry an oligopoly?, Transport Policy 16(5): 259-270. https://doi.org/10.1016/j.tranpol.2009.08.003

Tongzon, J. L. 2009. Port choice and freight forwarders, Transportation Research Part E: Logistics and Transportation Review 45(1): 186-195. https://doi.org/10.1016/j.tre.2008.02.004

Van de Voorde, E. E. M. 2005. What future the maritime sector?: Some considerations on globalisation, co-operation and market power, Research in Transportation Economics 13: 253-277. https://doi.org/10.1016/S0739-8859(05)13012-1

Wang, Y.; Cullinane, K. 2014. Traffic consolidation in East Asian container ports: a network flow analysis, Transportation Research Part A: Policy and Practice 61: 152-163. https://doi.org/10.1016/j.tra.2014.01.007

Woo, S.-H.; Pettit, S. J.; Kwak, D.-W.; Beresford, A. K. C. 2011. Seaport research: a structured literature review on methodological issues since the 1980s, Transportation Research Part A: Policy and Practice 45(7): 667-685. https://doi.org/10.1016/j.tra.2011.04.014

Yeo, H.-J. 2010. Competitiveness of Asian container terminals, The Asian Journal of Shipping and Logistics 25(2): 225-246. https://doi.org/10.1016/S2092-5212(10)80003-3

\section{Appendix A: Payoff calculations}

\section{(Case 1 and Case 5)}

\begin{tabular}{|c|c|c|}
\hline & Profit without Cooperation, $\pi_{i}^{\bar{C}}$ & Profit with Full Cooperation, $\pi_{i}^{C}$ \\
\hline 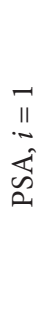 & $\begin{aligned} \pi_{1}^{\bar{C}, t=0} & =q_{1} \times\left(p_{1}-c_{1}\right) \\
& =30,000,000 \times(\mathrm{US} \$ 100-\mathrm{US} \$ 70) \\
& =\mathrm{US} \$ 900,000,000 \\
\pi_{1}^{\bar{C}, t=1} & =\bar{\pi}_{1}^{\mathrm{C}, t=0} \times\left(100+\delta_{1}\right) \% \\
& =\mathrm{US} \$ 900,000,000 \times 105.71 \% \\
& =\mathrm{US} \$ 951,390,000\end{aligned}$ & $\begin{aligned} \pi_{1}^{C, t=1} & =\pi_{1}^{\bar{C}, t=0}+\left(\frac{\alpha_{1}}{\alpha_{1}+\alpha_{2}+\alpha_{3}}\right)\left(\partial \times Q^{t-1}\right)\left(p_{1}-c_{1}\right) \\
& =\pi_{1}^{\bar{C}, t=0}+\left(\frac{63}{99}\right)(46,500,000 \times \partial)(\mathrm{US} \$ 30) \\
& =\mathrm{US} \$ 900,000,000+\mathrm{US} \$ 887,727,273 \times \partial\end{aligned}$ \\
\hline $\begin{array}{l}\hat{N} \\
\stackrel{n}{\|} \\
\hat{\vec{\theta}}\end{array}$ & $\begin{aligned} \pi_{2}^{\bar{C}, t=0} & =q_{2} \times\left(p_{2}-c_{2}\right) \\
& =9,000,000 \times(\mathrm{US} \$ 70-\mathrm{US} \$ 56) \\
& =\mathrm{US} \$ 126,000,000 \\
\pi_{2}^{\bar{C}, t=1} & =\pi_{2}^{\bar{C}, t=0} \times\left(100+\delta_{2}\right) \% \\
& =\mathrm{US} \$ 126,000,000 \times 114.00 \% \\
& =\mathrm{US} \$ 143,640,000\end{aligned}$ & $\begin{aligned} \pi_{2}^{C, t=1} & =\pi_{2}^{\bar{C}, t=0}+\left(\frac{\alpha_{2}}{\alpha_{1}+\alpha_{2}+\alpha_{3}}\right)\left(\partial \times Q^{t-1}\right)\left(p_{2}-c_{2}\right) \\
& =\pi_{2}^{\bar{C}, t=0}+\left(\frac{24}{99}\right)(46,500,000 \times \partial)(\mathrm{US} \$ 14) \\
& =\mathrm{US} \$ 126,000,000+\mathrm{US} \$ 157,818,182 \times \partial\end{aligned}$ \\
\hline
\end{tabular}




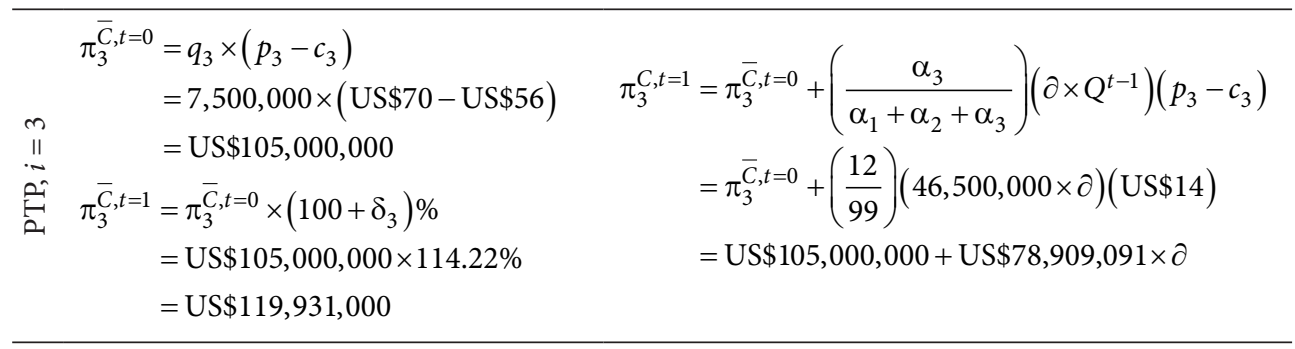

Situation where PSA \& PKL vs. PTP (Case 2)

\begin{tabular}{|c|c|}
\hline $\begin{array}{l}\text { PSA } \\
(\partial=7.62 \%)\end{array}$ & $\begin{aligned} \pi_{1}^{C, t=1} & =\pi_{1}^{\bar{C}, t=0}+\left(\frac{\alpha_{1}}{\alpha_{1}+\alpha_{2}}\right)\left(\partial \times Q^{t-1}\right)\left(p_{1}-c_{1}\right) \\
& =\pi_{1}^{\bar{C}, t=0}+\left(\frac{63}{87}\right)(39,000,000 \times 7.62 \%)(\mathrm{US} \$ 30) \\
& =\mathrm{US} \$ 900,000,000+\mathrm{US} \$ 64,559,793 \\
& =\mathrm{US} \$ 964,559,793\end{aligned}$ \\
\hline $\begin{array}{l}\text { PKL } \\
(\partial=7.62 \%)\end{array}$ & $\begin{aligned} \pi_{2}^{C, t=1} & =\pi_{2}^{\bar{C}, t=0}+\left(\frac{\alpha_{2}}{\alpha_{1}+\alpha_{2}}\right)\left(\partial \times Q^{t-1}\right)\left(p_{2}-c_{2}\right) \\
& =\pi_{2}^{\bar{C}, t=0}+\left(\frac{24}{87}\right)(39,000,000 \times 7.62 \%)(\mathrm{US} \$ 14) \\
& =\mathrm{US} \$ 126,000,000+\mathrm{US} \$ 11,477,297 \\
& =\mathrm{US} \$ 137,477,297\end{aligned}$ \\
\hline РTP & $\begin{aligned} \pi_{3}^{\bar{C}, t=0} & =q_{3} \times\left(p_{3}-c_{3}\right) \\
& =7,500,000 \times(\mathrm{US} \$ 70-\mathrm{US} \$ 56) \\
& =\mathrm{US} \$ 105,000,000 \\
\pi_{3}^{\bar{C}, t=1} & =\pi_{3}^{\bar{C}, t=0} \times\left(100+\delta_{3}\right) \% \\
& =\mathrm{US} \$ 105,000,000 \times 114.22 \% \\
& =\mathrm{US} \$ 119,931,000\end{aligned}$ \\
\hline
\end{tabular}

Situation where PSA \& PTP vs. PKL (Case 3)

\begin{tabular}{ll}
\hline$\pi_{1}^{C, t=1}$ & $=\pi_{1}^{\bar{C}, t=0}+\left(\frac{\alpha_{1}}{\alpha_{1}+\alpha_{3}}\right)\left(\partial \times Q^{t-1}\right)\left(p_{1}-c_{1}\right)$ \\
& $=\pi_{1}^{\bar{C}, t=0}+\left(\frac{63}{75}\right)(37,500,000 \times 8.05 \%)(\mathrm{US} \$ 30)$ \\
& $=\mathrm{US} \$ 900,000,000+\mathrm{US} \$ 76,072,500$ \\
& $=\mathrm{US} \$ 976,072,500$
\end{tabular}




\begin{aligned} \hline$\pi_{2}^{\bar{C}, t=0} & =q_{2} \times\left(p_{2}-c_{2}\right) \\ & =9,000,000 \times(\mathrm{US} \$ 70-\mathrm{US} \$ 56) \\ & =\mathrm{US} \$ 126,000,000 \\$ PKL & $\pi_{2}^{\bar{C}, t=1}=\pi_{2}^{\bar{C}, t=0} \times\left(100+\delta_{2}\right) \% \\ & =\mathrm{US} \$ 126,000,000 \times 114.00 \% \\ & =\mathrm{US} \$ 143,640,000 \\ \pi_{3}^{C, t=1} & =\pi_{3}^{\bar{C}, t=0}+\left(\frac{\alpha_{3}}{\alpha_{1}+\alpha_{3}}\right)\left(\partial \times Q^{t-1}\right)\left(p_{3}-c_{3}\right) \\ & =\pi_{3}^{\bar{C}, t=0}+\left(\frac{12}{75}\right)(37,500,000 \times 8.05 \%)(\mathrm{US} \$ 14) \\ & =\mathrm{US} \$ 105,000,000+\mathrm{US} \$ 6,762,000 \\ & =\mathrm{US} \$ 111,762,000\end{aligned}$

Situation where PKL \& PTP vs. PSA (Case 4)

\begin{tabular}{|c|c|}
\hline PSA & $\begin{aligned} \pi_{1}^{\bar{C}, t=0} & =q_{1} \times\left(p_{1}-c_{1}\right) \\
& =30,000,000 \times(\mathrm{US} \$ 100-\mathrm{US} \$ 70) \\
& =\mathrm{US} \$ 900,000,000 \\
\pi_{1}^{\bar{C}, t=1} & =\pi_{1}^{\bar{C}, t=0} \times\left(100+\delta_{1}\right) \% \\
& =\mathrm{US} \$ 900,000,000 \times 105.71 \% \\
& =\mathrm{US} \$ 951,390,000\end{aligned}$ \\
\hline $\begin{array}{l}\text { PKL } \\
(\partial=11.44 \%)\end{array}$ & $\begin{aligned} \pi_{2}^{C, t=1} & =\pi_{2}^{\bar{C}, t=0}+\left(\frac{\alpha_{2}}{\alpha_{2}+\alpha_{3}}\right)\left(\partial \times Q^{t-1}\right)\left(p_{2}-c_{2}\right) \\
& =\pi_{2}^{\bar{C}, t=0}+\left(\frac{24}{36}\right)(16,500,000 \times 11.44 \%)(\mathrm{US} \$ 14) \\
& =\mathrm{US} \$ 126,000,000+\mathrm{US} \$ 7,290,041 \\
& =\mathrm{US} \$ 133,290,041\end{aligned}$ \\
\hline $\begin{array}{l}\text { PTP } \\
(\partial=11.44 \%)\end{array}$ & $\begin{aligned} \pi_{3}^{C, t=1} & =\pi_{3}^{\bar{C}, t=0}+\left(\frac{\alpha_{3}}{\alpha_{1}+\alpha_{2}+\alpha_{3}}\right)\left(\partial \times Q^{t-1}\right)\left(p_{3}-c_{3}\right) \\
& =\pi_{3}^{\bar{C}, t=0}+\left(\frac{12}{36}\right)(16,500,000 \times 11.44 \%)(\mathrm{US} \$ 14) \\
& =\mathrm{US} \$ 105,000,000+\mathrm{US} \$ 3,645,021 \\
& =\mathrm{US} \$ 108,645,021\end{aligned}$ \\
\hline
\end{tabular}




\section{Appendix B: Characteristic function of superadditive}

$$
\begin{aligned}
& U(P S A+P K L+P T P) \\
= & \sum_{i=1}^{3} \pi_{i}^{C, t=1} \\
= & \pi_{1}^{C, t=1}+\pi_{2}^{C, t=1}+\pi_{3}^{C, t=1} \\
= & (\mathrm{US} \$ 900,000,000+\mathrm{US} \$ 887,727,273 \times \partial)+(\mathrm{US} \$ 126,000,000+\mathrm{US} \$ 157,818,182 \times \partial) \\
& +(\mathrm{US} \$ 105,000,000+\mathrm{US} \$ 78,909,091 \times \partial) \\
= & (\mathrm{US} \$ 1,131,000,000)+(\mathrm{US} \$ 1,124,454,546) \times \partial ; \\
& U(P S A)+U(P K L)+U(P T P) \\
= & \sum_{i=1}^{3} \pi_{i}^{C, t=1} \\
= & \pi_{1}^{C, t=1}+\pi_{2}^{\bar{C}, t=1}+\pi_{3}^{C}, t=1 \\
= & \mathrm{US} \$ 951,390,000+\mathrm{US} \$ 143,640,000+\mathrm{US} \$ 119,931,000 \\
= & \mathrm{US} \$ 1,214,961,000 .
\end{aligned}
$$

Hence, $U(P S A+P K L+P T P) \geq U(P S A)+U(P K L)+U(P T P)$ and we obtain $[(\mathrm{S} \$ 1,131,000,000)+(\mathrm{US} \$ 1,124,454,546) \times \partial] \geq \mathrm{US} \$ 1,214,961,000$

$$
\partial \geq 0.0747
$$

where $\partial$ is the annual growth of container traffic (TEUs), which is the breakeven point for the three ports to decide whether to cooperate or not to cooperate. 